\title{
Developing Students' Critical Thinking on Speaking Through Socratic Questioning Method
}

\author{
Yayuk Hayulina Manurung, Fatimah Sari Siregar \\ University of Muhammadiyah Sumatera Utara \\ yayukhayulina@umsu.ac.id
}

\begin{abstract}
This research was carried due to the lack of students' critical thinking at English department on speaking. Answering questions were approximately found more popular than asking questions. Socratic questioning is a method of learning with the conversation or debate confronted with a series of questions. The research used descriptive qualitative design by collecting the documents, observation and interview data. Then the data was analyzed by using qualitative data analysis with Miles and Huberman data analysis by covering data collection, data display and conclusion drawing/verification. The result showed that the appearance of Socratic Question varied from the easiest to the most difficult. Percentage of the result showed that ten point five percent belonged to clarification, twenty one percent belonged to assumption, twenty five point five percent belonged to reason and evidence thirty one point five percent belonged to viewpoints, twenty five point five percent for implication and consequences, and ten point five percent for questions to question. The interview data from the lecturer showed that Socratic Questioning method could improve not only students' speaking skill but also their critical thinking even though some obstacles faced during teaching and learning process such as; self-confidence problem, the lack of grammar and vocabularies, lack for knowledge background relating to the material, data, fact and evidence.
\end{abstract}

Keywords-critical thinking; Socratic questioning; speaking

\section{INTRODUCTION}

English learning is a compulsory subject in the English Department of FKIP University Muhammadiyah of Sumatera Utara in accordance with the curriculum in Indonesia. Therefore all students are expected to master four English skills especially on speaking skill. Because today, being able to speak English in this respect English recognized as an international language is important because of the era of globalization that gives people unlimited contact with each other around the world where today more than a billion people use English through the media social or also face to face (Brown, 2001). While in the field of education critical thinking is very important to be taught and applied. The ability to think critically gives the students the ability to not only understand what they have read or have proven but also to build that knowledge without additional guidance. Critical thinking teaches them that knowledge is fluid and self-building. It is not just rote memory or the ability to absorb the lessons without asking. critical thinking products and programs encourage them to think for themselves, question the hypothesis, develop alternative hypotheses, and to test their hypotheses against known facts. Critical thinking skills can not develop spontaneously. The lecturer should play the role of giving instruction by initiating and guiding critical thinking. Critical thinking can be about any topic, content, or problem where thinkers improve quality in thinking by analyzing skillfully. They do not think critically, they cannot generate their ideas and send them. In fact more students prefer to be silent than talking.

However, in the process of teaching and learning in English Department there are some findings mostly dealing with how far students' critical thinking is. One of the first thing to note is that answering questions are more popular than asking questions, even almost no questioning activity among students during the lecture takes place. This phenomenon is not surprising because usually the time allocated for questioning is very little, not more than 10 minutes, sometimes not even given at all. Portraiture of learning like this is not entirely student error, which is often considered less bold, less confident, and less creative. However, if lecturers' self-evaluation is done in term of how often they ask questions to students either at the beginning, middle or end of the lecture, and whether the questions are able to encourage students to think critically or the questions asked are only at the remembering level, the lowest level in the latest version of taxonomy Bloom (Anderson \& Krathwohl, 2001) thus it causes them not to think critically.

Then not all every lecturer considers a lot about what techniques are appropriate to apply to motivate students to speak. Socrates technique is still seldom applied in teaching speaking. In fact this technique requires students to respond to questions given by lecturers where they should think and analyze first before giving orally. Some experts also explain about this technique. According to Modzierz et all (2014) argued that the Socrates technique is a systematic interrogation technique that provides a series of questions designed to facilitate students' independent thinking. This implies that this 
technique provides an activity in which the lecturer provides a series of questions that require students to analyze critically and independently, and then they respond to them verbally.

This study aimed to describe the implementation of students' critical thinking through Socrates Questioning Method in speaking subject at English Department University of Muhammadiyah Sumatera Utara. The significance of this research is practically having relation with improving the students' critical thinking in accordance with the development of spoken language communication activities.

\section{METHODS}

This descriptive qualitative research sought to find out the improvement of students' critical thinking on speaking subject through Socratic questioning method. The subject of the study was the second year students of University of Muhammadiyah Sumatera Utara, Medan in the first academic year of 2016/2017. There were 35 students.

To obtain the supporting data in this study, some forms of technique were used. Among others were:

a. Close observation technique, the researcher acted as non-participant observer and didn't participate and interfere in teaching speaking subject. A checklist was also given each time Socratic questioning method appeared

b. Video and audio recording, every activity among lecturer and students was recorded

c. Interview technique, which was used to measure the improvement students' critical thinking through Socratic questioning method. The students were given 4 questions relating the implementation of the method through lecture' problems.

Furthermore the research data was analyzed by using qualitative analysis, code data and look for themes related to the research focus. In analyzing the data, the researcher concerned with the components of data analysis in interactive model proposed by Miles and Huberman (1994). 


\section{FINDING AND DISCUSSION}

The result showed that the frequency of Socratic questions varied from the easiest to the hardest ones.

Table 1. The Appearance of Socratic Question Type

\begin{tabular}{|c|c|c|c|}
\hline No & $\begin{array}{l}\text { Types of Socratic } \\
\text { Questions }\end{array}$ & Examples questions & Total \\
\hline 1. & $\begin{array}{l}\text { Questions } \\
\text { clarification }\end{array}$ & $\begin{array}{l}\text { What is nature of human trafficking? } \\
\text { Could you give an example of human trafficking? } \\
\text { Why do you think so? } \\
\text { Could you say it has to do with slavery? }\end{array}$ & 3 \\
\hline 2. & $\begin{array}{l}\text { Questions that probe } \\
\text { assumptions }\end{array}$ & $\begin{array}{l}\text { What can you assume about the cause of human trafficking? } \\
\text { What can you assume the global human trafficking? } \\
\text { Please describe how far the human trafficking appears in } \\
\text { Indonesia? }\end{array}$ & 6 \\
\hline 3. & $\begin{array}{l}\text { Questions that probe } \\
\text { reason and evidence }\end{array}$ & $\begin{array}{l}\text { Why hasn't human trafficking got the solution until now? } \\
\text { How far does Indonesian government overcome this issue? } \\
\text { Can you show how many victims of it and how are they now? } \\
\text { How do you know the poverty also influence the human } \\
\text { trafficking action? } \\
\text { Can you mention what level of society mostly becomes the } \\
\text { victim? } \\
\text { Who are the men behind this crime? }\end{array}$ & 7 \\
\hline 4. & $\begin{array}{l}\text { Questions } \\
\text { viewpoints } \\
\text { perspective }\end{array}$ & $\begin{array}{l}\text { Is there any intense investigation for this issue? } \\
\text { Are children dominated victims? } \\
\text { What factors cause the existence of human trafficking until now? } \\
\text { What does the police institution do to decrease this problem? } \\
\text { What will happen in the future if the matter still appears for youth } \\
\text { generation }\end{array}$ & 9 \\
\hline 5. & $\begin{array}{l}\text { Questions that probe } \\
\text { implications and } \\
\text { consequences }\end{array}$ & $\begin{array}{l}\text { So what will happen if this issues still appear } \\
\text { What will happen to youth generation then? } \\
\text { What is the worst image of world in the future for global human } \\
\text { trafficking? }\end{array}$ & 7 \\
\hline 6. & $\begin{array}{l}\text { Questions } \\
\text { question }\end{array}$ & Why do I give the human trafficking as the material? & 3 \\
\hline
\end{tabular}




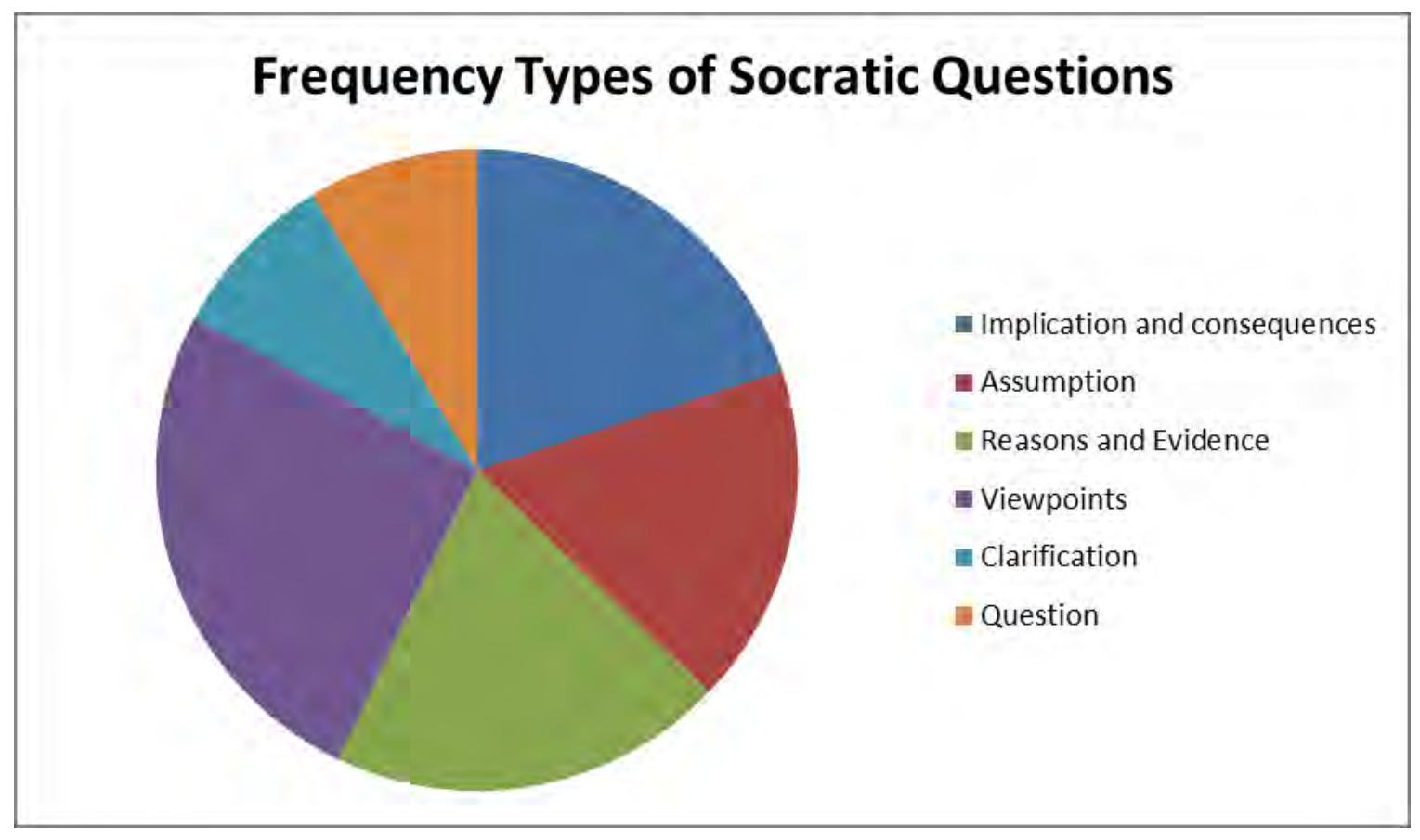

Interview result showed that the lecturer stated that the Socratic questioning method incredibly was not only able to optimize students' skill in speaking but also their critical thinking. The obstacles such their self-confidence, their lack in building statements with the good grammar and structures, limited resources and data in giving scientific argument and then difficult questions to be answered however didn't block them to improve their critical thinking meeting by meeting.

Paul (2006) stated that Socratic questioning is at the art of critical thinking. There is a special relationship between critical thinking and Socratic questioning because both share a common end. Critical thinking gives one a comprehensive view of how the mind functions (in its pursuit of meaning and truth), and Socratic Questioning takes advantage of that overview to frame questions essential to the quality of that pursuit. Socratic questioning is a systematic process for examining the ideas, questions, and answers that form the basis of human belief. It involves recognizing that all new understanding is linked to prior understanding that thought itself is a continuous thread woven throughout lives rather than isolated sets of questioning and answers. Questioning is an important activity for students to dig information, analyzing and explore idea Nurhadi (2002). Furthermore, Cooper (1990) explains that to questioning well is to teach well. In the skill use of the question more than anything else lay the find art of teaching. For in it we have the guide to clear and vivid ideas, and the quick spire to imagination, the stimulus to thought, the incentive to action, what's in questioning, you ask? Everything. It is the way to evoking stimulating response or stultifying inquiry. It is, in essence, the vey care of teaching, the art of guiding learning.

Deep questions drive thought underneath the surface of things, force to deal with complexity (Paul, 2006). Questions of purpose force to define task, look at source of information, examine how to organize or give meaning to information, consider alternative ways of giving questions and also follow out where thinking is going.

Each type of Socratic question which appeared in research findings provided understanding related to critical thinking. First, conceptual clarification questions let the students think more about what exactly they were asking or thinking about. They proved the concepts behind their argument and applied basic "tell me more" questions to go deeper. Second, probing assumption questions made them think about the presuppositions and unquestioned beliefs on which they were finding their argument. This was shaking the bedrock and should get them what it is really going. Third, probing rationale, reason and evidence questions supported them to dig into that reasoning rather than assuming what it was given while people often use un-thought-through or weakly understood supports for their arguments. Fourth, viewpoint and perspective questions focused on the most particular position given. In this session they attacked the position and showed that there were other equally valid viewpoints. Fifth, implication and consequences questions focused on the desirable argument. The last, question about question could also get reflexive about the whole thing, turning the question in on itself. The students attacked and bounced themselves into their court. 
The research findings on the six types of Socratic question mostly on viewpoint, reason, and evidence while question about question and clarification were less used. It means that both the lecturer and the students need to explore more on the six types of Socratic questions and can use it equally to dig much information that lead to the lecturer and students' critical thinking.

Meanwhile, through the Socratic method of questioning, students practiced deep thinking which paved the way to the construction of a new knowledge and helped them generate more meaningful ideas and robust answers.

Speaking is an interactive process of constructing meaning that involves producing, receiving and processing information (Brown, 1994). Its form and meaning are dependent on the context in which it occurs, including the participants themselves, their collective experiences, the physical environment, and the purpose of speaking. Furthermore, Nunan (2006) reminds that teaching speaking is also to teach the students to be able to produce the English spoken sound and pattern, use word and sentences stress, intonation patterns and rhythm of the language, select appropriate words and sentences according to the proper social setting, audience, situation and subject matter, organize their thoughts in a meaningful and logical sequence, use language as a means of expressing values and judgments, and use the language quickly and confidently with few unnatural pauses which are called as fluency. From the research findings, it can be seen that Socratic questioning method influenced students' critical thinking through their speaking ability. Their ability in reasoning and expressing thoughts were reflected on their speaking performance. They explored the information as much as possible about the current issues, collected the trusted data resource, evidence and facts, constructed the arguments and shared the experiences.

The findings of this research confirmed the previous similar research result by Ross (2003) and Hadi (2012). Socratic questioning method is a dynamic format for helping the students to take the genuine intellectual risks in the classroom and to learn to think critically. It is encouraging them to optimize their thinking through questioning productive, systematic, and purposeful and depth thought. It enables them to steer the task and decipher the root of problems clearly. Socratic questioning method undoubtedly improves the students critical thinking through their speaking performance.

\section{CONCLUSION}

Applying Socratic questioning method on speaking subject at second year students of English department university of Muhammadiyah Sumatera Utara does not only improve their speaking performance but also their critical thinking. The appearance of Socratic questioning varies from the easiest to the most difficult. Some obstacles found during the research are such as self-confidence problem, grammar, structure and vocabulary problems, limited knowledge background related to the issues given, the lack of data, fact and evidence resources, less experience about the topic and difficulty faced in conducting questions to be given.

The lecturers should be well prepared with the material and types of Socratic questions and they should be more creative in creating active and fun class environment. Then preparing multimedia to make the material more easily accepted by the students becomes the solution for limited students' background knowledge in understanding the material given. At last this method can be also applied in teaching different material by modifying it in appropriate context.

\section{References}

Anderson, L.W \& Krathwohl. (2001). A Taxonomy for Learning, Teaching, and Assessing: A Revision of Bloom's Taxonomy of Educational Objectives (Complete edition). New York: Longman.

Brown, H.D. (1994). Teaching by Principles : an Interactive Approach to Language Pedagogy. Englewood Cliffs, NJ:Prentice Hall Regents.

Cooper. (1990). Effective Teaching and Learning: Teacher's and Student's Perspective. U.S : University Press.

Hadi, W. (2012). The Implementation of Questioning strategy in teaching Speaking for the First Level of English Course.Madura: Institut Prima Bhakti English Course.

Miles, M.B \& Huberman, A. M. (1994). An Expanded Sourcebook Qualitative Data Analysis (2 ${ }^{\text {nd }}$ Ed). United States of America:Sage Publication.

Mozdzierz, G., P. R. Peluso \& J. Lisiecki. (2014). Advanced Pinciples of Counseling and Psychotherapy : Learning, Integrating and Nunan, David. 1999. Second Language Teaching and Learning. Boston: Heinle and Heinle Publisher.

Nunan, D. (2006). Language Teaching Methodology. UK: Prentice Hall International.

Nurhadi. (2002). Pendekatan Kontekstual (Contextual Teaching and Learning). Jakarta: Depdiknas Dirjeb Dikdasmen. Ross. (2003). Speaking of Teaching Using Socratic Method. USA: Stanford University. 